\title{
鎖骨々折を伴った環軸椎亜脱臼の一症例
}

国立小倉病院整形外科

$\begin{array}{ccccc}\text { 野 呂 純 敬・芳 賀 } & \text { 晸 } \\ \text { 塩 田 悦 仁・井 原 和 彦 } \\ \text { 久米整形外科 }\end{array}$

久米祥生

\section{A Case of Atlanto-axial Rotatory Fixation with Fracture of the Clavicle}

by

\author{
Yoshihiro Noro, Bin Haga, Etsuji Shiota, Kazuhiko Ihara \\ and Yoshio Kume \\ Orthopedic Surgery, Kokura National Hospital
}

\begin{abstract}
A case of atlanto-axial rotatory fixation with fracture of the right clavicle, in which traction therapy had failed, was treated satisfactorily with manipulation under general anesthesia. This patient was a 5-year-old boy without evidence of rheumatic disease or fracture of the dens.
\end{abstract}

$$
\text { はじめに }
$$

環軸関節が回旋位のまま固定し斜頸位が持続する症 例については，以前より様々な用語があり，その概念 については，以前より一定したものがないのが現状で ある. わが国では神中ら妾の用いた炎症性斜頸という 用語が一般的であった. 今回我々は銷骨々折を伴った 本症を経験したので報告する。

症例

\section{5 才 男児}

昭和 58 年 5 月 23 日, 直径 $40 \mathrm{~cm}$ 程の穴のあいた ブロックの中に頭部より転落. 即ちに近医を受診. 右 銷骨々折之診断されギプス固定を受けた．翌朝，左側 に顔を向けたまま頸部の回旋ができなくなっているの に母親が気づき，項部痛・運動時の疼痛増悪を訴える ため他医を受診. 銷骨バンドにて 3 週間の固定をうけ たが，斜頸位の方は全く改善がみられないため，当科 を紹介された。

初䛦封，頭頸部は約 $30^{\circ}$ 右へ傾き，左へは 30 $50^{\circ}$ 回旋可能であったが，右への回旋はほとんど不能 であった，検査データーは，CRP：十，血沈：1時間
值 25，2 恃間値 60，その他の血液所見は正常であり， 神経症状はみられなかった，X線では，右銷骨々折の 他は，項部痛のため十分な開口位が得られずはっきり した所見は得られなかった．再侧中耳炎の 既往，I血 沈，CRP 等加ら炎症性斜頸を疑い，通院にて変形機 珹矯正を 3 週間行なったが，斜頸位は改善がみられな かった.

受傷後 30 日目，正面開口位撮影でははっきりした 所見は得られず, 断層撮影では環椎前弓後面・脢笑起 間距離は $3 \mathrm{~mm}$ であった。

受傷後 60 日目，断買撮影にて $7 \mathrm{~mm}$ の琹椎侧方偏 位を認め (図 1), 血沈の改善, CRP の陰性化をみた ため，環軸椎亜脱曰と部断した。

受傷後 72 日目，入院. 翌日全身矂醉下にて徒手整復 を試みた．頸椎をわずか亿過伸展位とし，頭部を長軸 方向に轩引しながら左へ約 $45^{\circ}$, 次化右へ約 $90^{\circ}$ 回旋 した．わずかの抵抗と同時にググッという整復音があ った，その後は，左右とも回旋の制限はなくなり，ボ 一ル紙カラーにて固定し， $2 \mathrm{~kg}$ の仯吾にて顔面を 正 面に保持したまま病室に戻り，その後はグリソン第引 を $1.5 \mathrm{~kg}$ にて行なった.

整復後 40 日目，X線にても 屈曲伸展位でのアライ 


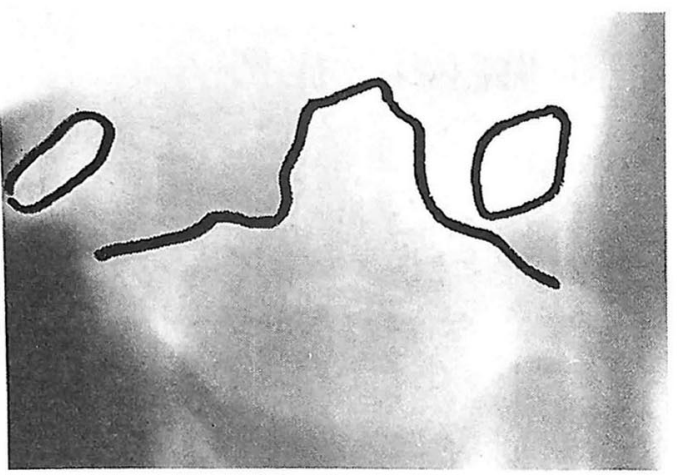

図1受㑺後60日目の正面断奥挹影 㻴椎の侧方偏位は $7 \mathrm{~mm}$ であ る.

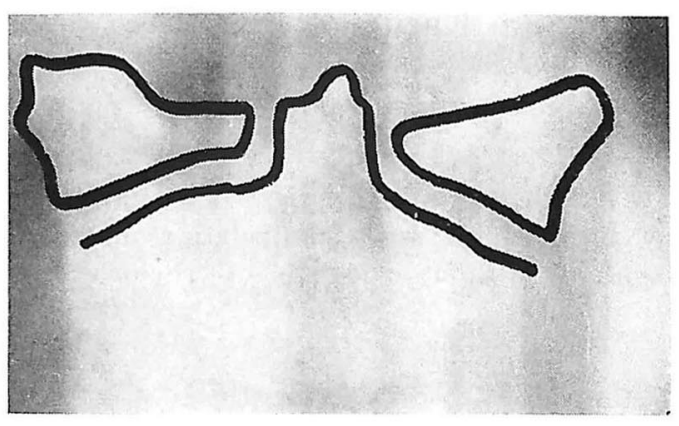

図 2 整復後51日目の正面断尿撮影 㻴椎の侧方偏位以全く見られ ない。

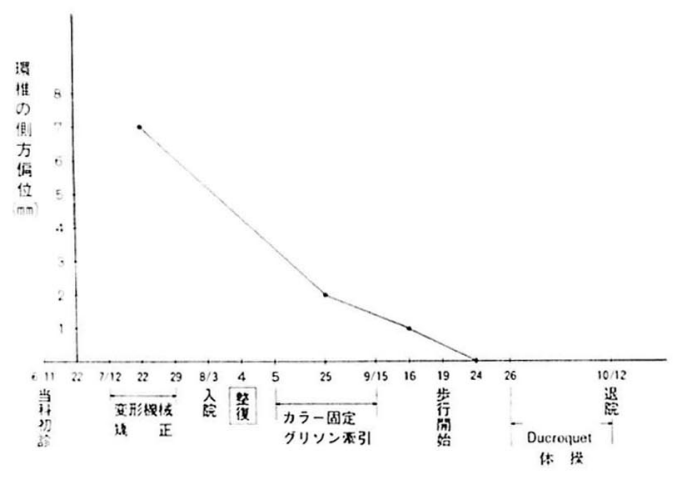

図3環椎側方偏位の变移と治療経過

ンメントの乱れはみられず，環椎の側方偏位は $1 \mathrm{~mm}$, 器椎前弓後面・崡焭起間距離は $4 \mathrm{~mm}$ となり, グリ ソン亲引を中止，ソフトカラー装着の上，ベッド上生 活を自由とした。

整復後 51 日日， $\mathrm{X}$ 線上嗅椎の倒方偏位は全くみら れなくなり（四 2 ），斜莖位も消失，存への回旋も可
能となっていた. Ducroquet 休操を開始した.

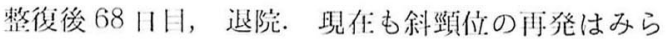
れていない.

以トの経過を刚 3 に亦す。

考察

平非ら は, 怪症例に刘して atlanto-axial rotatory dislocation or subluxation と呼び, 難治例に 刘して atlanto-axial rotatory fixation と呼ぶのが 触当であるとしており, 徒来の炎症性斜頸は前者に含 まれるとしている.したがって，本症例は atlantoaxial rotatory fixation と呼ぶべきであるかむしれ ない.

$\mathrm{X}$ 線像で器椎の側方偏位が们 $\mathrm{mm}$ あれば州脱目 あるいは脱臼と認めるかについては定説はなく, Wortzmann ら ${ }^{8)}$ は, 回旋老排除して $1 \mathrm{~mm}$ 以内の 侧方偏位は正常笵囲であるとする合意があるようだ， と述べている. 環椎前弓後面と歯突起前面との距離に ついては，正常を Steele ${ }^{7)}$ は，成人 $3 \mathrm{~mm}$ ，小児 4 $\mathrm{mm}$, Jackson ${ }^{3)}$ は, 成人 $2.5 \mathrm{~mm}$, 小児 $4.5 \mathrm{~mm}$ ま でとしている.回旋位の証明については，環檕関節の 左右非刘称により行なう ${ }^{5}$.

Atlanto-axial rotatory fixation の分類について は, Fielding ら の分類があり，本症は前方脱臼を 伴わない Type I と思われる.

また治撚法としては，䇛引療法が一般的であるが， 本症例の場合，他に重篤な合侀症むなく発症後すでに 10 週以上経ており, 症状む固定していたため, 早期に 環軸惟の良好な位置関係を得るべきと考え，全身㑣醉 下に徒手整復を試みた ${ }^{6)}$.

$$
\text { ま と め }
$$

我々は，右鎖骨々折を伴った在斜頸位を経験し，X 線にて atlanto-axial rotatory fixation と渗断し た. 制引療法にても長期間改善がみられないため, 全 身麻唒下に徒手整復を試みたところ，良好な結果を得 ることができた。

$$
\text { 文献 }
$$

1) Fielding, J. W. et al: Atlanto-axial rotatory fixation, (Fixed rotatory subluxation of the atlanto-axial joint), J. Bone Joint Surg., 59-A : 37-44, 1977. 
2) 平非三知夫ほ か：Atlanto-axial rotatory fixation の榆討, 整形 - 災需外科, 23: 897-909, 1980.

3) Jackson, H.: The diagnosis of minimal atlanto-axial subluxation. Br. J. Radiol. 23 : $672,1950$.

4) 神中正一ほ加：耳獭咽頭性斜頸の整形外科的観 察. 日整会誌. 6: 165, 1931.

5）片山直樹ほか：小児の骨折を伴わない atlanto-axial rotatory fixation について, 整形外 科, 32: 121-128, 1981.

6）加藤 正ほ加：左鎖骨骨折を伴った環軸関節亜 脱臼の 1 例，関東整災誌，11：52-56，1980.

7) Steele, H. H.: Anatomical and mechanical considerations of the atlanto-axial articulations. J. Bone Joint Surg. 50-A: 1481, 1968.

8) Wortzmann, G., et al.: Rotatory fixation of the atlanto-axial subluxation. Radiology, 90: 479-487, 1968.

\section{発 言毞児島大学 富村吉十郎}

私共も鎖骨々折を伴った環軸椎覀脱臼の 1 症例を経 験しております．7才，男児で横断歩道を歩行中乗用 車にはねられ受傷し，近医で鎖骨々折に対しギプス包 帯固定をうけています．ギプス固定中に母親が斜頸位
に気づいていますが，銷骨々折によるすのと放郘され ていましたが，骨施合後も斜頸位が続くため，受伤後 約 7 力月目に某大学病院にて環粙椎の回旋性垔脱臼を 指摘され，当科に紹介され入院いたしました.

入院後 skulltraction の後, McGraw 法にて後方 固定術を行ないましたが，斜頸位は怪度残存していま す. 敛骨々折に気をとられるあまり，上位頸椎の病変 が見のがされていたものであります.

質 問 総合脊惟センター 佐々木邦焳

1. 鎖骨々折を伴なったとの演題名をつけられたの は,メカニズム等で何か特殊なととを考えられたから ですか.

2. 整復後, Ducroquet を使用されていますが，そ の理由をお教え下さい.

解 答国立小倉病院 野虽 純敬

1. 鎖骨々折に目を奪われて，监なる炎症性のもの として扱われる恐れああると考えたからです.

2. 包帯报去直後は，恐怖心のため自発的に頸を動 かそうとしないため，その間の 1 stepとして行ないま した. 